\title{
ERGONOMIC IMPROVEMENT IN OPERATOR SEAT AND CONTROLS OF SMALL TRACTOR
}

\author{
O. L. Kolekar ${ }^{1}$,J. M. Potekar ${ }^{2}$ \\ ${ }^{I}$ P.G. Student, College of Agriculture Engg. \& Tech., MAU Parbhani \\ ${ }^{2}$ Head, Department of Farm Machinery and Power, College of Agriculture Engg \& Tech., MAU Parbhani -431402
}

\begin{abstract}
Ergonomics is the field of study that examines human behavior, psychological and physiological capabilities and can design and modify established work environment to maximize, the productivity worker's comfort and overall efficiency. Modern agricultural industry is inclined towards high speed, power and efficient agricultural tractor. The nature of tasks on a tractor necessitates a number of actions to be performed by the operator, which puts varying physiological demands on the body. Making these tasks injury and stress-free for the driver is a challenge for the designer.

This project was intended to make Ergonomic improvements in company's 15hp tractor. The customer feedback about the seeding batch of the tractor was obtained, based on which modifications were made in the design of the tractor for better ergonomics. The activities in the project included checking the workplace design measurements as per Budni recommendation, benchmarking with competitor tractors, study of anthropometric data of Indian population, analysis of the tractor controls for force and vibration limitations. Various improvement areas were identified and the necessary changes were made in the seat dimensions, improvement is done in operator's seat as per IS 12343 (1998) standard and anthropometric details i.e. $5^{\text {th }}$, 50 $0^{\text {th }}$ and $95^{\text {th }}$ percentile of selected persons. Location and orientation of steering and other controls of the tractor, this improvement was done as per BS, ISO.IS standard and Indian customer survey report - Budni. These modifications were implemented on the existing tractor. To validate the improvements, and checking the workplace design measurements as per Budni recommendation after improvement, a survey was performed taking 25 operators before \& after the modifications. The results of the survey indicated a remarkable improvement in driver's comfort, reachability of controls and visibility
\end{abstract}

Keywords:-Ergonomics, tractor, seating comfort, safety, anthropometry, design modifications, percentile workplace, force, vibration. ****

\section{INTRODUCTION}

Ergonomics (Human Engineering) is the scientific study of relationship between man and his working environment. The term environment includes his tools and materials, his methods of work, ambient condition and physical environment of work, also the organization of work. Importance of ergonomics has been well established and recognized in industry and military application. However, it is equally important and relevant in agriculture and related activities also. In most of the developing countries human workers constitute as one of the important sources of farm power. Besides, they also operate tractors, power tillers, self propelled machines and power operated machines. Therefore, in agriculture also, the application of ergonomics can help in increasing the efficiency and therefore, in agriculture also, the application of ergonomics can help in increasing the efficiency and there by productivity of the worker without jeopardizing their health.
India is the largest market for the below $37 \mathrm{~kW}$ tractor in the world, due to small size of land holding. The current population of tractor and power tillers in the India is around 2.5 and 0.18 millions, respectively. India today stands as the largest manufacturer of the tractors in world (Singh and Doharey, 1999). They are being mainly used for primary and secondary tillage operations and as a means of transportation to haul goods, peoples and even animals. The self- propelled machines are about 0.04 million and include combines, selfpropelled reapers, threshers etc. they are used for harvest and post harvest operations.

The primary factions of a tractor seat include the need to locate the tractor operator in a position from where he can operate the tractor safely with all around vision and experiences reduced vibration levels. The operator must also 
feel comfortable in cushion material of the seat. Moreover, an extended period of sitting results in a high risk of back problems, discomforts in buttocks due to surface pressure and discomfort in legs and feet from pressure under the thigh (Floyd and Roberts, 1958). Keeping in view the above requirements in operator seat and controls of $15 \mathrm{HP}$ tractor, an investigation was undertaken with the following major objectives 1) To study and improve in operator seat of $15 \mathrm{HP}$ 2)To study and improve controls of 15 HP tractor.

\section{MATERIAL AND METHODS}

This Chapter deals with the description of experiments and techniques employed in measurement of essentials characteristics of ergonomic improvement in seat of small tractors.

\subsection{Selection of Small Tractors}

Four small tractors are selected for Workplace design measurements which are as follows

$\begin{array}{cl}\text { i. } & \text { Tractor 1. }(18.5 \mathrm{HP}) \\ \text { ii. } & \text { Tractor 2. }(35.5 \mathrm{HP}) \\ \text { iii. } & \text { Tractor } 3 .(29 \mathrm{HP}) \\ \text { iv. } & \text { Tractor } 4 .(15 \mathrm{HP})\end{array}$

In which we choose the Tractor 1(18.5 HP), Tractor 2(35.5 HP) Tractor 3 (29 HP, is selected because of it is small hence measurement of data which is for important for improvement in Tractor 4 (15 HP).

\subsubsection{Workplace Design Measurement of Selected} Tractor

Following are the procedure for Workplace design measurement for selected agricultural tractor.

\subsubsection{Procedure}

Take unballast tractor on a levelled plain surface with Check an air inflation pressure of both the Rear \& front wheels \& maintain it to 20 psi \& 28 psi also Check the total longitudinal travel of seat \& seat is to be fixed at middle point of total adjustment. Then Mount Seat Index Point fixture on seat. With Place the $55 \mathrm{~kg}$ calibrated weight on fixture centre, then Put plumb on seat back rest on seat \& locate the seat reference point with adjusting the vertical column such that distance from SRP is $140 \mathrm{~mm}$ and Mark $90 \mathrm{~mm}$ distance on this vertical column. Then Check the vertical column perpendiculars by using spirit level bevel protractor for Marking $400 \mathrm{~mm}$ distance on vertical column from SIP. After all arrangement Connect Longitudinal Rod on vertical column. Also check the longitudinal column plain parallel using spirit level bevel protractor. Then Connect Lateral Rod to Longitudinal Rod, Check the lateral column plain parallel using spirit level bevel protractor. After this Move the Lateral Rod on Longitudinal Rod adjust the longitudinal distance on
Longitudinal Rod so as to plumb at LH side. Then Plot the plumb on Lateral Rod to clutch pedal centre \& measure the vertical, longitudinal and lateral distances.

Actual vertical Distance from SIP $=$ Measured vertical distance $-400 \mathrm{~mm}$

Same procedure follows for Foot accelerator, brake pedal, diff -lock pedal, steering wheel, high low lever, PC-DC lever etc.

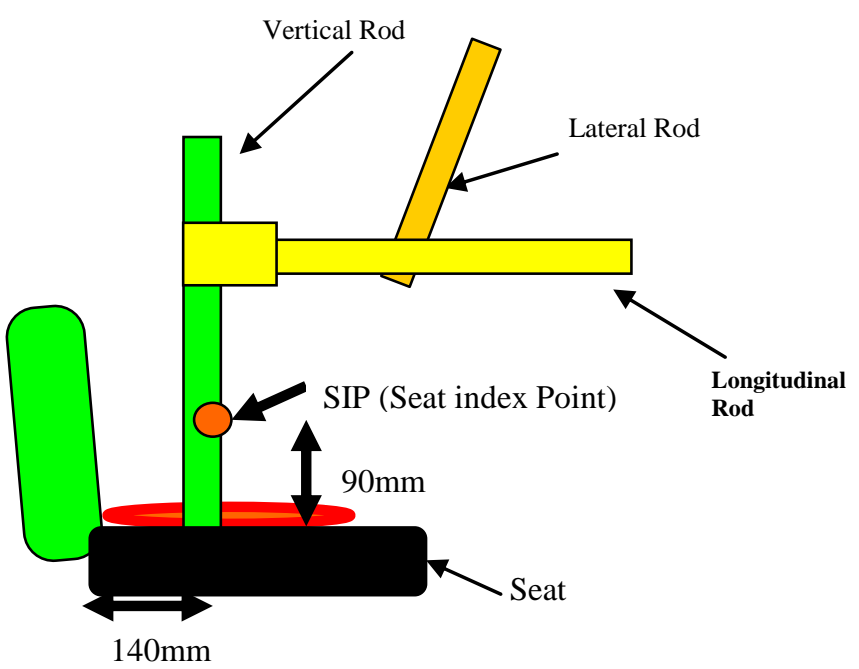

Fig.2.1 Arrangement for Workplace design measurement of tractor

\subsection{Measurement Steering Angle}

A Workplace design measurement of tractor includes the measurements of steering angle and it is done by using 'Bevel protector' a bevel protector is a circular or semicircular tool for measuring an angle or a circle. The utilized are usually degrees. Bevel protector has one or two swinging arm which can be used to help measure the angle. Also bevel protector is a graduated circular protector having a pivoted arm, used for measuring or marking of lines.

\subsection{Selection of Person for Taking Observation (Feed}

\section{Back)}

In selection of person following considerations can be adopted, Persons are having the different height; Persons are having different state in which our tractors are sealing. Also consider the regions such as north region and south region etc.

The demographical data taken as name, address, region, region is taken for the in which our tractor is seals in that region e.g. Maharashtra, Also take the driving experience on tractor because exact answer is depends upon the experience hence we take the driving experience of operator on tractor.The 
anthropometric data taken as Height in $\mathrm{mm}$, weight in $\mathrm{kg}$. Hand length in $\mathrm{mm}$ (hand length is upper most shoulder to the tip of middle finger), Foot length in $\mathrm{mm}$, Eye height (seating) in mm, Body girth (at seating) in $\mathrm{mm}$.

Weighing machine, $3 \mathrm{~m}$ measuring tape, Marker and Steel scale- 1 foot these instrument are used for anthropometric measurement.

After selecting persons they seat on tractors seat of different tractors and fill up the question sheet. Question sheet is prepared according to the Borg's rating. Then after filling the Question sheet it is simplifies in 'MS- EXCEL' after simplifies go head for determining the improvement areas and take appropriate action in these areas for improvement in operator seat and controls of $15 \mathrm{HP}$ tractor.
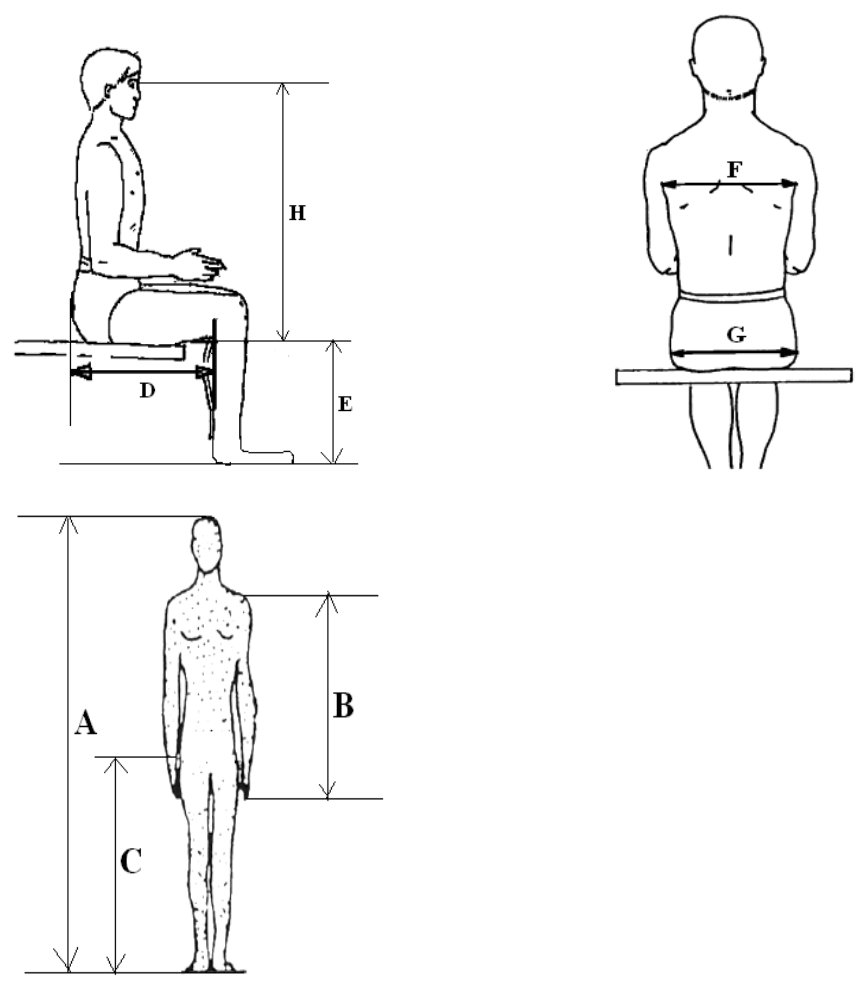

Fig.2.2 Anthropometric dimensions for tractor seat design according to NASA Anthropometric Source Book (NASA, 1978): (A) Height, or Stature (B) Hand length, (C) Functional leg length (D) Buttock popliteal length, (E) Popliteal height
(F) Interscye breadth. (G) Hip breadth sitting, (H) Eye height, sitting

\subsection{Force Limits for Actuating Various Controls}

As the pedals are moved laterally from the middle of the leg, the force executable decreases and the discomfort increases (Lehman, 1958). The Indian standard IS: 10703-1992 specifies the limits for actuating forces for the various controls. These are given in following table. Measurements of various controls are essential for the operator comfort and check standard and actual are equal.

Instrument used for measurement of the forces activating various controls

\subsection{Electrical Load Cell}

An electrical load cell is a device (Transducer) that is used for convert a force in the electrical signal. This conversion is indirect and happens in two stages. Through a mechanical arrangement, the force being sensed deforms a strain gauge. The Strain gauge converts deformation (strain) to electric signal. A load cell usually consists of four strain gauges in a Wheatstone bridge configuration.

\subsection{Push-Pull Gauge}

A push pull gauge is a device also used for the force measurements it is used for the force measurements of gear shifting lever in the case of push pull the controls. Push pull gauge has a limit of $30 \mathrm{kgf}$.

\subsection{Measurement of Vibration Transmitted in}

\section{Tractor}

Comfort in farm machinery units requires the absence of unpleasant intrusions. Vibration is the principle cause of discomfort in tractors. The vibration level is dependent primarily on factor such as driving surface, speed, the RPM of the engine, the type of seat, the kind of tires and the construction of the machine. After measurements of vibration on seat and controls check whether it is in limit or not. Vibration analyzer is used for measure vibration of improved tractor i.e. tractor 4 (15 HP)

\section{RESULTS AND DISCUSSION}

\subsection{Seat Details}

\begin{tabular}{|l|l|l|l|l|}
\hline & & & & Recommendations as per \\
Tractor model & $\begin{array}{l}\text { As per IS 12343 } \\
(1998)\end{array}$ & $\begin{array}{l}\text { Tractor 4 } \\
(15 \quad \text { HP) } \\
\text { OLD }\end{array}$ & $\begin{array}{l}\text { Tractor 4 } 4 \text { Anthropometric data of } \\
(\mathbf{1 5} \text { HP) }\end{array}$ & $\begin{array}{l}\text { NEW } \\
\text { selected persons \& Indian } \\
\text { customer survey report } \\
\text { Budni }\end{array}$ \\
\hline Seat Pan & & & & \\
\hline
\end{tabular}




\begin{tabular}{|c|c|c|c|c|}
\hline Length (mm) & $400+/-50$ & 340 & 380 & $\begin{array}{l}\text { Buttock popliteal length }\left(5^{\text {th }}\right. \\
\text { percentile) } 370 \pm 10\end{array}$ \\
\hline Width (mm) & $>450$ & 430 & 450 & $\begin{array}{l}\text { Hip breadth setting }\left(95^{\text {th }}\right. \\
\text { percentile } 444 \& \text { as per Budni } \\
430)\end{array}$ \\
\hline Thickness (mm) & NA & 45 & 70 & \\
\hline Inclination with horizontal (degree) & $\begin{array}{l}3^{\circ} \text { to } 12^{\circ} \\
\text { backward }\end{array}$ & $2^{\circ}$ & $4^{\circ}$ & $3^{\circ}$ to $7^{\circ}$ \\
\hline $\begin{array}{l}\text { Height of the Seat pan surface from the } \\
\text { floor }(\mathrm{mm})\end{array}$ & $540(\max )$ & 500 & 465 & $\begin{array}{l}\text { Sitting buttock popliteal length } \\
95^{\text {th }} 510\end{array}$ \\
\hline \multicolumn{5}{|l|}{ Seat Backrest } \\
\hline Height (mm) & $>260$ & 265 & 265 & 250 actual back rest \\
\hline Width (mm) & $>450$ & 305 & 430 & $\begin{array}{l}\text { Interscye breadth } 95 \quad \text { th } \\
\text { percentile } 410\end{array}$ \\
\hline Thickness (mm) & NA & 40 & 60 & 60 (uncompress) \\
\hline Inclination with horizontal (degree) & $\begin{array}{l}95^{\circ} \text { to } 105^{\circ} \text { from } \\
\text { the horizontal }\end{array}$ & $93^{\circ}$ & $97^{\circ}$ & $\begin{array}{l}95^{\circ} \text { to } 105^{\circ} \text { from the } \\
\text { horizontal. }\end{array}$ \\
\hline $\begin{array}{l}\text { Gap Between Steering Wheel \& Seat } \\
\text { Pan }\end{array}$ & NA & & & \\
\hline$\overline{\text { Horizontal gap }(\mathrm{mm})}$ & NA & 210 & 110 & \\
\hline Inclined Gap (mm) & NA & 290 & 200 & \\
\hline Steering column angle & & $79^{\circ}$ & $68^{\circ}$ & \\
\hline Steering Wheel dia. $(\mathrm{mm})$ & & 410 & 410 & \\
\hline \multicolumn{5}{|l|}{ Seat Curvature details } \\
\hline Sample width of pan ( X ) & NA & 430 & 450 & $\begin{array}{l}\text { Hip breadth setting } \quad\left(95^{\text {th }}\right. \\
\text { percentile } 444 \quad \& \text { as per Budni } \\
430)\end{array}$ \\
\hline Observed Depth ( Y ) & NA & 30 & 35 & \\
\hline $\begin{array}{l}\text { Calculated Seat Pan - Curvature Radius } \\
(\mathrm{mm})\end{array}$ & NA & 785 & 751 & Minimum 750 \\
\hline Sample width of backrest, ( X ) & $>450$ & 305 & 430 & $\begin{array}{l}\text { Interscye breadth } 95{ }^{\text {th }} \\
\text { percentile } 410\end{array}$ \\
\hline Observed Depth backrest, ( Y ) & NA & -- & -- & -- \\
\hline $\begin{array}{l}\text { Calculated Seat backrest } \text { Curvature } \\
\text { Radius (mm) }\end{array}$ & NA & -- & -- & -- \\
\hline Contours & & $\begin{array}{ll}\text { only } & \text { Seat } \\
\text { pan }\end{array}$ & $\begin{array}{ll}\begin{array}{l}\text { only } \\
\text { pan }\end{array} & \text { Seat } \\
\end{array}$ & \\
\hline Seat mounting & & -- & -- & \\
\hline $\begin{array}{l}\text { Total travel adjustment }(\mathrm{mm}) \\
\text { Horizontal }\end{array}$ & NA & 50 & 50 & -- \\
\hline - Vertical & \begin{tabular}{|l}
++-100 opt $(+/-25$ \\
optimum)
\end{tabular} & No & No & -- \\
\hline Gap between Seat Pan \& Backrest (mm) & NA & 55 & 55 & \\
\hline $\begin{array}{l}\text { Total travel adjustment }(\mathrm{mm}) \\
\text { Horizontal }\end{array}$ & \begin{tabular}{|l|l|}
.$+/-50 o p t$ & $(+/-25$ \\
optimum)
\end{tabular} & 50 & 50 & -- \\
\hline - Vertical & & No & No & -- \\
\hline $\begin{array}{ll}\text { Vertical distance }(\mathrm{mm}) & \text { - Steering } \\
\text { Wheel Center from SIP } & \\
\end{array}$ & & 220 & 176 & 170 to 475 above \\
\hline Seat cushion material & NA & Dunlop & Dunlop & $\begin{array}{l}\text { Dunlop material has better } \\
\text { resiliency property }\end{array}$ \\
\hline
\end{tabular}




\subsection{Statistical Analysis Anthropometry Measurement of Selected Person}

\begin{tabular}{|l|l|l|l|l|l|l|l|l|l|}
\hline $\begin{array}{l}\text { Sr. } \\
\text { No. }\end{array}$ & $\begin{array}{l}\text { Height } \\
(\mathbf{m m})\end{array}$ & $\begin{array}{l}\text { Weight } \\
(\mathrm{kg})\end{array}$ & $\begin{array}{l}\text { Hand } \\
\text { Length } \\
(\mathbf{m m})\end{array}$ & $\begin{array}{l}\text { Functional } \\
\text { leg length } \\
(\mathbf{m m})\end{array}$ & $\begin{array}{l}\text { Buttock } \\
\text { popliteal } \\
\text { length }(\mathbf{m m})\end{array}$ & $\begin{array}{l}\text { Popliteal } \\
\text { height } \\
(\mathbf{m m})\end{array}$ & $\begin{array}{l}\text { Interscye } \\
\text { breadth } \\
(\mathbf{m m})\end{array}$ & $\begin{array}{l}\text { Hip } \\
\text { breadt } \\
\text { h } \\
\text { Sitting } \\
(\mathbf{m m})\end{array}$ & $\begin{array}{l}\text { Eye } \\
\text { Height } \\
\text { Seating } \\
(\mathbf{m m})\end{array}$ \\
\hline $\begin{array}{l}5^{\text {th }} \\
\text { percentile }\end{array}$ & 1614 & 49.52 & 666.6 & 953.4 & 390.2 & 415.2 & 312 & 311 & 690 \\
\hline $\begin{array}{l}\mathbf{5 0}^{\text {th }} \\
\text { percentile }\end{array}$ & 1714 & 68.5 & 740 & 1040 & 450 & 470 & 354 & 362 & 750 \\
\hline $\begin{array}{l}95^{\text {th }} \\
\text { percentile }\end{array}$ & 1807.4 & 80.804 & 803.2 & 1192 & 510.4 & 527.8 & 385 & 444 & 770 \\
\hline
\end{tabular}

\subsection{Statistical Analysis of Anthropometries Data}

This is the statistical analysis of taking measurement of 25 persons for taking observation. This value of $5^{\text {th }}, 50$ th and $95^{\text {th }}$ percentile value are directly taken for the improving seat dimension

\subsection{Solving the Questioner of 25 Persons}

Following are the graphical presentation of the analysis of questioner

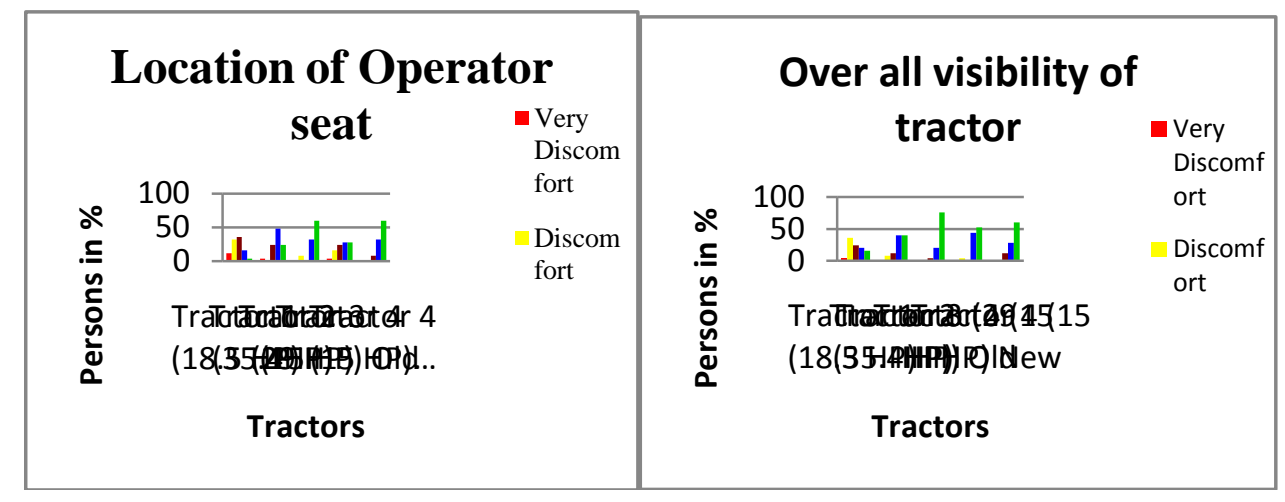

Fig.3.1 Location of operator seat

Fig. 3.2 Overall visibility of tarctors.

From Fig. 3.1 it clear that $60 \%$ persons are very comfortable in Tractor 3 and tractor $4(\mathrm{New})$ for Location of operator seat.
And Fig. 3.2 it clear that $76 \%$ persons are very comfortable in tractor 3 and $60 \%$ persons are very comfortaable in tractor 4 .

\begin{tabular}{|c|c|c|c|c|c|c|}
\hline & & $\begin{array}{r}\text { Ister vis } \\
\text { tract }\end{array}$ & $\begin{array}{l}\text { ty of } \\
\text {-Very }\end{array}$ & & $\begin{array}{l}\text { Discomfort in } \\
\text { Buttock/Back }\end{array}$ & - Very \\
\hline 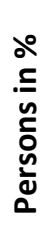 & $\begin{array}{r}100 \\
0\end{array}$ & $\begin{array}{l}\overline{\left.\right|_{1.1} \|_{L} \mid} \\
\text { TrTr.... } \\
\text { Tractor }\end{array}$ & $\begin{array}{l}\text { Disc } \\
\text { omf } \\
\text { ort }\end{array}$ & 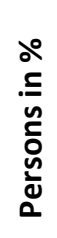 & 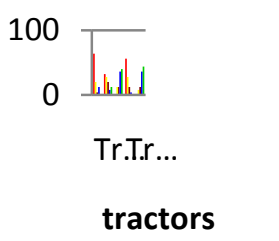 & $\begin{array}{l}\text { Disc } \\
\text { omf } \\
\text { ort }\end{array}$ \\
\hline
\end{tabular}

Fig.3.3 Cluster visibility of Tractors

Fig. 3.4 Discomfort in buttock/back 
From Fig. 3.3 it clear that $44 \%$ persons are very comfortable in Tractor 3 and tractor $4(\mathrm{New})$ for Location of operator seat Fig. 3.4 it clear that $44 \%$ persons are very comfortable in tractor 4 (New) and $40 \%$ persons are very comfortaable in tractor 3 .

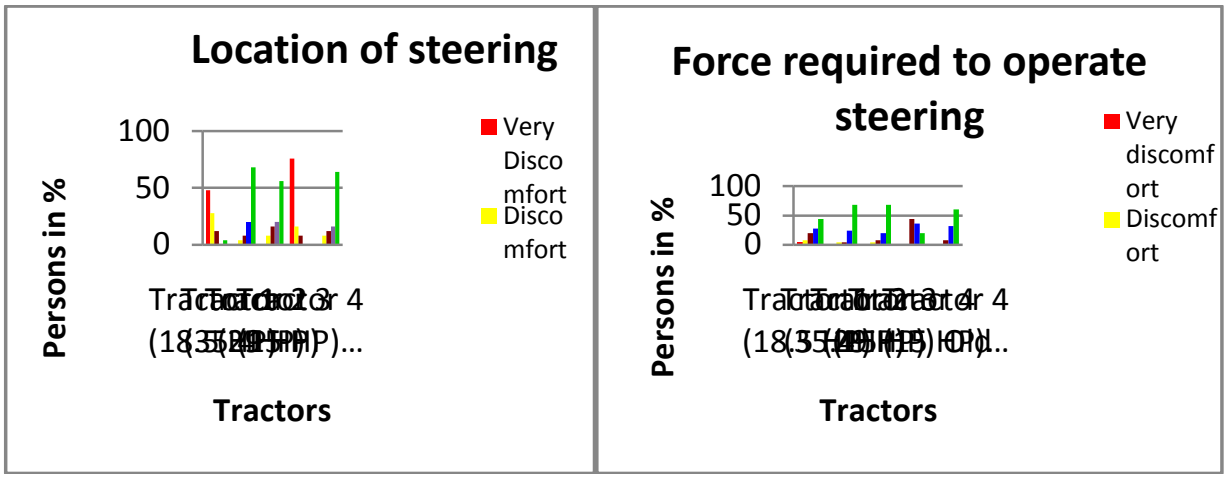

Fig. 3.5 Location of Steering

Fig. 3.6 Force required to operate Steering.

From Fig. 3.5 it clear that $68 \%$ persons are very comfortable in tractor 2 and $64 \%$ persons are very comfortaable in tractor 4(New) for Location of Steering. And Fig. 3.6 It clear that

$68 \%$ persons are very comfortable in tractor 2 and tractor 3 for force reqired to operate steering.

\subsection{Force Measurement after Improvement}

Following are force measurement after improvement of tractor 4 (15 HP). Which are in the limit

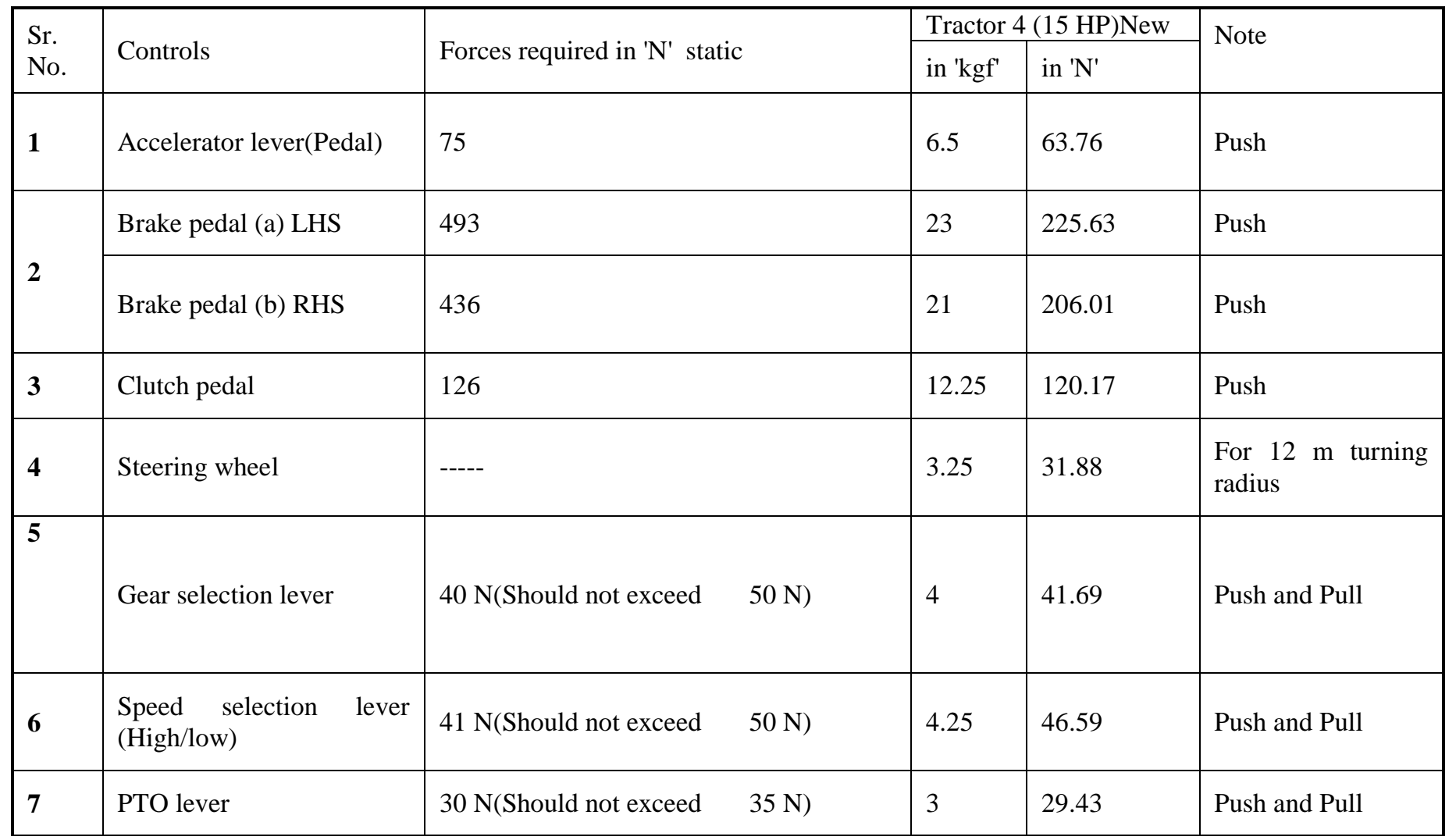




\begin{tabular}{|l|l|l|l|l|l|}
\cline { 3 - 6 } 8 & & & \\
\hline $\mathbf{9}$ & Hand throttle lever & 34 N(Should not exceed 40 N) & 4 & 39.24 & Push and Pull \\
\hline \multirow{9}{*}{} & $\begin{array}{l}\text { Hydraulic levers } \\
\text { a)Draft control lever }\end{array}$ & For DC Control Lever40 N & 4 & 39.42 & Push and Pull \\
\cline { 2 - 7 } & b)Position control lever & For PC Control Lever 25 N & 2.25 & 22.07 & Push and Pull \\
\hline
\end{tabular}

\subsection{Vibration Measurement after improvement}

Table shows Vibration measurement after improvement in Tractor 4 (15 HP), which is in limit.

\begin{tabular}{|c|c|c|c|c|c|c|c|c|c|c|}
\hline \multirow{3}{*}{$\begin{array}{l}\text { Sr } \\
\text {.no } \\
.\end{array}$} & \multirow{3}{*}{ Levers } & \multirow{2}{*}{$\begin{array}{l}\text { As per } \\
\text { recommendat } \\
\text { ion }\end{array}$} & \multicolumn{4}{|c|}{ Displacement } & \multicolumn{4}{|c|}{ Acceleration } \\
\hline & & & \multicolumn{2}{|c|}{$\begin{array}{l}\text { Vertical } \\
\text { displacement }\end{array}$} & \multicolumn{2}{|c|}{$\begin{array}{l}\text { Horizontal } \\
\text { displacement }\end{array}$} & \multicolumn{2}{|c|}{$\begin{array}{l}\text { Vertical } \\
\text { displacement }\end{array}$} & \multicolumn{2}{|c|}{$\begin{array}{l}\text { Horizontal } \\
\text { displacement }\end{array}$} \\
\hline & & \multirow{15}{*}{$\begin{array}{l}\text { as per standard } \\
\text { Displacement } \\
\text { should not } \\
\text { excide } 100 \\
\text { microns and } \\
\text { acceleration } \\
\text { should not } \\
\text { excide } 1 \text { 'g' }\end{array}$} & in 'mm' & $\begin{array}{l}\text { in } \\
\text { micron } \\
\end{array}$ & in 'mm' & $\begin{array}{l}\text { in } \\
\text { micron } \\
\end{array}$ & $\begin{array}{l}\text { in } \\
\mathrm{m} / \mathrm{s}^{21}\end{array}$ & in ' $\mathrm{g}$ ' & $\begin{array}{l}\text { in } \\
\mathrm{m} / \mathrm{s}^{21}\end{array}$ & in ' $\mathrm{g}$ ' \\
\hline 1 & $\begin{array}{l}\text { Accelerator lever } \\
\text { (hand) }\end{array}$ & & 0.09 & 90 & 0.09 & 90 & 9.3 & 0.948 & 9.8 & 0.9989 \\
\hline 2 & $\begin{array}{l}\text { Accelerator lever } \\
\text { (foot) }\end{array}$ & & 0.1 & 100 & 0.095 & 95 & 4.8 & 0.4892 & 5.8 & 0.5912 \\
\hline 3 & Brake pedal (a) LHS & & 0.07 & 70 & 0.08 & 80 & 8.1 & 0.8256 & 9.2 & 0.9378 \\
\hline 4 & Brake pedal (b) RHS & & 0.07 & 70 & 0.07 & 70 & 8.1 & 0.8256 & 10 & 1.019 \\
\hline 5 & Clutch pedal & & 0.08 & 80 & 0.07 & 70 & 7.4 & 0.7543 & 9.3 & 0.948 \\
\hline 6 & Steering wheel & & 0.095 & 95 & 0.09 & 90 & 9.9 & 1.0091 & 9.6 & 0.9785 \\
\hline 7 & Gear selection lever & & 0.08 & 80 & 0.1 & 100 & 4.4 & 0.4485 & 6.1 & 0.6218 \\
\hline 8 & $\begin{array}{l}\text { Speed selection lever } \\
\text { (High/low) }\end{array}$ & & 0.09 & 90 & 0.085 & 85 & 5.6 & 0.5708 & 10 & 1.0193 \\
\hline 9 & PTO lever & & 0.04 & 40 & 0.6 & 60 & 4.4 & 0.4485 & 8.9 & 0.9072 \\
\hline 10 & Hand throttle lever & & 0.06 & 60 & 0.07 & 70 & 3.8 & 0.3873 & 5 & 0.5096 \\
\hline 11 & $\frac{\text { Hydraulic levers }}{\text { a)Draft control lever }}$ :- & & 0.07 & 70 & 0.08 & 80 & $9 . .2$ & 0.9378 & 10 & 1.019 \\
\hline 12 & $\begin{array}{l}\text { b)Position control } \\
\text { lever }\end{array}$ & & 0.08 & 80 & 0.07 & 70 & 6 & 0.6116 & 5.5 & 0.5606 \\
\hline 13 & operator Seat & & 0.1 & 100 & 0.1 & 100 & 6.1 & 0.6218 & 4.1 & 0.4179 \\
\hline 14 & flower panal & & 0.05 & 50 & 0.08 & 80 & 9.4 & 0.9582 & 10 & 1.01937 \\
\hline
\end{tabular}




\begin{tabular}{|l|l|l|l|l|l|l|l|l|l|l|}
15 & Fender - LHS & 0.08 & 80 & 0.095 & 95 & 10.5 & 1.0703 & 9.8 & 0.9989 \\
\hline 16 & Fender - RHS & 0.08 & 80 & 0.09 & 90 & 10 & 1.0193 & 9.9 & 1.009 \\
\hline
\end{tabular}

\section{SUMMARY AND CONCLUSIONS}

Conclusions are as follows:

1. The tractor after ergonomic modifications was measured and tested for compliance with the Budni recommendations for tractor workspace design, and was found to be OK.

2. The tractor operators in the survey found that modified tractor is safe and comfortable for driving.

3. The forces were measured by load cell and push-pull gauge were found to be within the physiological force limits specified by the standards IS: 10703-1992.

4. The vibrations measured by hand analyzer after modification was found to be within limits specified by the standard ISO 2041: 1990, ISO 6007.

\section{REFERENCES}

[1] Floyd, W. F., Roberts, D. F., 1958. Anatomical and Physiological principles in chair and table design, Ergonomics 2(1), 1-16.

[2] Gerke, f. G. Hoag, D. L., 1981. Tractor vibrations at the operator's stations. Transaction of ASAE 24(2), 1131-1134

[3] Gite, L. P. and Singh, G.1997. Ergonomics in agricultural and allied activity in India. Technical bulletin No. CIAE/97/70. Central Institute of Agricultural Engineering, Nabilagh, Bhopal.

[4] Grandjean, E., 1988. Fitting the task to the man. Taylor and Francis, London.

[5] International Organization For Standardization 1997 ISO 2631-1 (E). Mechanical vibration and shock*Evaluation of human exposure to whole-body vibration. Part 1: General requirements.

[6] IS 12343, (1988) technical requirements for operator's seat of agricultural tractors.

[7] ISO 4253, 1993. Agricultural tractors- Operator's seating accommodation - Dimension. International Organization for standardization, Geneva.

[8] ISO 5353, 1984. Earth moving machinery and tractors and machinery for Agricultural and Forestry- seat Index Pint. International Organization for standardization, Geneva.

[9] Lehmann G. Physiological basis of tractor design. Ergonomics 1958;1(3):197-206.

[10] Mehta, C.R., 2006. Ergonomic assessment of existing tractor seats. Technical Report (RPF III), Central Institute of Agricultural Engineering, Bhopal, India.

[11] Murphy, D. J., 1992. Safety and Health for production agriculture. ASAE, St. Joseph, Michigan. 